\title{
White Cell Serology: An Asset for Selective Blood-DNA Extraction from Mixed Stains for STR Analysis
}

Suminder Kaur*, Barkha Budhiraja, Garima Chaudhary, Vaishnavi N and Ritika Gupta

Forensic Science Laboratory Sector, Delhi, India

\begin{abstract}
Forensic analysis of mixed DNA samples poses a potential challenge for the investigator. Male-female mixed DNA samples in sexual assault cases are commonly analyzed in forensic laboratory but in case of male-male and female-female mixed DNA sample from multiple perpetrators in sexual assaults (gang rapes) and homicide cases, it is not easy to discriminate the origin of different donors. We present a protocol for mixed blood stain samples involving agglutination of leukocytes with $A B O$ antisera and using the separated leukocytes for DNA profiling. By using this technique, we were able to differentiate the leukocytes of different individuals. DNA profiles were obtained using AmpF $\ell$ STR identifiler plus amplification kit.
\end{abstract}

Keywords: White cell antigens; Serology; STRs; DNA; Mixed blood stains; Identifiler plus; Mixed DNA profile; DNA typing

\section{Introduction}

Biological samples for forensic analysis primarily consist of blood, semen, hairs, and saliva. Laboratory investigations involving biological fluids play a vital role in crime investigations. Proper collection and preservation of the evidence is of essence as improper collection and preservation can weaken or destroy a potential source of facts in a case. The suspects may hide valuable blood stain evidence either on an object or the clothes in different conditions which may affect the investigation. Therefore, proper collection and preservation of blood stain is important, as it may provide a link between an individual and a criminal act [1]. In homicide cases, there are chances of getting mixed blood samples when more than one perpetrator/victim is involved.

In 1985, Gill et al. [2] showed that sperm nuclei can be separated from vaginal cellular debris in case of semen-contaminated vaginal swabs. This has, in fact, revolutionized forensic biology with regard to identification of rape suspects. Mixed DNA contains the DNA from two or more contributors, in this scenario, the first and important task for the investigator is to establish the number of contributors. Male-female mixed DNA differentiation is easily performed in forensic laboratories but male-male or female-female DNA sample poses a challenge. Mixed DNA samples as forensic evidence has become a challenge for forensic researchers due to lack of reliable processing methods. Appropriate experimental techniques are needed for mixed DNA analysis [3].

When DNA profiling is performed using STR markers, presence of more than two peaks is not easy to interpret. It can be due to chimerism or because of mixing of DNA sample [1]. Possibility of chimerism can be excluded by investigating the clinical history of the person involved. For the possibility of mixed DNA sample, selective DNA extraction using cell-specific antibodies would be a useful alternative method.

Selective cell-specific blood typing using white cell antigens prior to DNA profiling can be used as an effective tool for the problem of mixed blood sample. Selective cell-specific blood typing involves the absorption of specific antibody by the corresponding white cells from an individual of a certain blood group. White cells express antigens that are shared with other cells of the body, i.e., red cells and platelets because despite the diversity of the nature, morphology, characteristics and function of the blood cells, it is presently believed that there is a single progenitor, which is capable of self regeneration and by exposure to growth factors becomes dedicated to a specific lineage [4].

The method followed use of white cell antigens and A, B and $\mathrm{H}$ antisera to separate specific white cells in a mixed blood sample. Separated white cells can be then used for DNA extraction and STR analysis for identification.

\section{Materials and Method}

\section{Sample preparation}

Fresh blood was collected from three healthy individuals having blood group genotype 'AA', 'BO' and 'OO'. Clinical history of all three individuals has been checked and possibility of chimerism has been excluded. $200 \mu \mathrm{l}$ of each liquid blood type was mixed in a $2 \mathrm{ml}$ microcentrifuge tube and then $200 \mu \mathrm{l}$ of this mixed liquid blood was placed on two cotton gauzes which were dried at room temperature.

\section{Separation of white cells and DNA typing}

Selective collection of human blood cells was performed by using three cuttings of the stain $\left(1 \mathrm{~cm}^{2}\right)$ in three microcentrifuge tubes labelled as A, B and O. $1 \mathrm{ml}$ saline was added in the tubes, vortexed and incubated for 1 hour at $37^{\circ} \mathrm{C}$. Anti-A, anti-B and anti-H lectin were added to the respective tubes ( $\mathrm{A}, \mathrm{B}$ and $\mathrm{O}$ ) and incubated for 10 minutes at $37^{\circ} \mathrm{C}$. These microcentrifuge tubes were then centrifuged at $500 \mathrm{~g}$ for 5 minutes and the supernatant was separated. The pellet obtained was dissolved in $30 \mu \mathrm{TE}$ buffer and preserved at $4^{\circ} \mathrm{C}$. A drop of sample was then placed on FTA $^{\text {mw }}$ paper, dried and processed for DNA extraction.

Separated white blood cells processed after ABO serology was used for DNA profiling. DNA amplification was performed using AmpFeSTR identifiler Plus kit. This kit consists of one Amelogenin and

*Corresponding author: Suminder Kaur, Senior Forensic Examiner (Asst. Dir.) Forensic Science Laboratory Sector 14, Rohini, Delhi 110085, India, Tel: 91 09899563299; E-mail: ksuminder@gmail.com

Received December 28, 2015; Accepted February 25, 2016; Published February 29, 2016

Citation: Kaur S, Budhiraja B, Chaudhary G, Vaishnavi N, Gupta R (2016) White Cell Serology: An Asset for Selective Blood-DNA Extraction from Mixed Stains for STR Analysis. J Forensic Res 7: 319. doi:10.4172/2157-7145.1000319

Copyright: (C) 2015 Kaur S, et al. This is an open-access article distributed unde the terms of the Creative Commons Attribution License, which permits unrestricted use, distribution, and reproduction in any medium, provided the original author and source are credited. 
Page 2 of 3

\begin{tabular}{|c|c|c|c|c|c|c|c|c|c|}
\hline \multirow{2}{*}{$\begin{array}{c}\text { Loci } \\
\text { D8S1179 }\end{array}$} & \multicolumn{2}{|c|}{ AA } & \multirow{2}{*}{$\begin{array}{l}A^{*} \\
14\end{array}$} & \multicolumn{2}{|c|}{ BO } & \multirow{2}{*}{$\begin{array}{c}\mathbf{B}^{*} \\
13,15\end{array}$} & \multicolumn{2}{|c|}{00} & \multirow{2}{*}{$\begin{array}{c}\mathbf{O}^{*} \\
10,13,15\end{array}$} \\
\hline & 14 & 14 & & 13 & 15 & & 10 & 15 & \\
\hline D21S11 & 29 & 33 & 29,33 & 29 & 31.2 & $29,31.2$ & 31 & 32.2 & $29,31,31.2,32.2$ \\
\hline D7S820 & 11 & 11 & 11 & 10 & 12 & 10,12 & 8 & 8 & $8,10,12$ \\
\hline CSF1PO & 10 & 12 & 10,12 & 10 & 11 & 10,11 & 12 & 13 & $10,11,12,13$ \\
\hline D3S1358 & 15 & 18 & 15,18 & 15 & 16 & 15,16 & 15 & 16 & 15,16 \\
\hline TH01 & 7 & 8 & 8,9 & 8 & 9.3 & $8,9.3$ & 6 & 9.3 & $6,8,9.3$ \\
\hline D13S317 & 12 & 13 & 12,13 & 8 & 11 & 8,11 & 8 & 11 & 8,11 \\
\hline D16S539 & 11 & 11 & 11 & 9 & 11 & 9,11 & 10 & 11 & $9,10,11$ \\
\hline D2S1338 & 20 & 24 & 20,24 & 19 & 23 & 19,23 & 18 & 19 & $18,19,23$ \\
\hline D19S433 & 13 & 13.2 & $13,13.2$ & 14 & 15.2 & $14,15.2$ & 14 & 14.2 & $14,14.2,15.2$ \\
\hline vWA & 16 & 16 & 16 & 16 & 17 & 16,17 & 15 & 18 & $15,16,17,18$ \\
\hline TPOX & 11 & 11 & 11 & 8 & 8 & 8 & 11 & 11 & 8,11 \\
\hline D18S51 & 15 & 15 & 15 & 13 & 14 & 13,14 & 15 & 17 & $13,14,15,17$ \\
\hline D5S818 & 11 & 13 & 11,13 & 10 & 12 & 10,12 & 11 & 13 & $10,11,12,13$ \\
\hline FGA & 24 & 25 & 24 & 21 & 24 & 21,24 & 21 & 24 & 21,24 \\
\hline AMELOENIN & $x$ & Y & $X, Y$ & $x$ & $x$ & $X, X$ & $x$ & $x$ & $X, X$ \\
\hline
\end{tabular}

Table 1: Allelic data of pure DNA from ' $A$ ', 'B' and 'O' blood type individuals respectively; ' $A$ *', ' $B$ *' and 'O*' represents the allelic data obtained after processing the mixed blood stain sample with $\mathrm{A}, \mathrm{B}$ and $\mathrm{H}$ antisera respectively.

15 autolocus markers (D8S1179, D21S11, D7S820, CSF1PO, D3S1358, TH01, D13S317, D16S539, D2S1338, D19S433, vWA, TPOX, D18S51, D5S818, FGA).

Capillary electrophoresis of the amplified products was carried out on $\mathrm{ABI} 3500 \mathrm{xL}$ genetic analyzer (PE). Data was analyzed by using Gene Mapper ID-X software. In-house control along with the kit control has also been used.

\section{Results and Conclusion}

We were able to recover the complete DNA profiles of all three individuals corresponding to their $\mathrm{ABO}$ blood types from the mixed stains. This selective cell-specific blood typing along with DNA profiling using multiplex STR has proven highly successful in the recovery of DNA profiles corresponding to the ABO blood type using AmpFeSTR identifiler Plus kit (Table 1 and Figure 1). In case of the ${ }^{1}$ pure profiles, blood types showed both homozygous (showing one allele) and heterozygous (showing two alleles) conditions. In case of the processed $\mathrm{A}^{*}, \mathrm{~B}^{\star}$, and $\mathrm{O}^{\star}$, it was possible to successfully obtain pure ' $\mathrm{A}$ ' and ' $\mathrm{B}$ ' profiles while in case of $\mathrm{O}^{\star}$, the profile showed intermixing of ' $\mathrm{B}$ ' profile along with 'O' profile (Figure 2).

Based on the results obtained, mixed blood samples when processed using combination of serology and subsequent DNA analysis showed pure $A$ and $B$ profiles when treated with $A$ and $B$ antisera respectively. Whereas in case of processed ' $O$ ' cells, when the mixed blood stains were treated with $\mathrm{H}$-antiserum, its DNA profile revealed alleles from both $\mathrm{B}$ and $\mathrm{O}$ blood type cells, thereby indicating the presence of $\mathrm{H}$-antigen in the genotype of B blood type. Therefore, it can be concluded that the genotypes of the individuals from whom the blood was collected is AA, $\mathrm{BO}$ and $\mathrm{OO}$.

As mentioned earlier by Honda et al. [5], if only two person mixtures are involved in forensic casework, we can find from one (minimum) to four (maximum) alleles present at any locus. However, interpretation of the four alleles is not always easy and is dependent upon the state of the sample and clinical history of the donor of the sample.

It is thereby concluded that combination of serology with subsequent DNA analysis for mixed blood samples can extensively be used in solving forensic cases. In case of gang rapes and homicide 'Pure denotes the DNA profile of 'A', 'B' and 'O' blood group individuals. cases involving multiple perpetrators, analysis of mixed DNA profiles from identifiler or Y-filer amplification kits can be challenging but using serology followed by DNA profiling technique can increase the discrimination power in mixed DNA samples with ease and accuracy.

\section{Discussion}

In forensic examinations, it is crucial to identify total number of perpetrators contributed to a mixed DNA sample. Interpretation of more than two allelic bands per locus is very important as it may be due to various reasons. Additional band may be present as a result of stutter or somatic/genetic polymorphism, this can be excluded by examining the allelic peak, which should be within $\pm 0.5 \mathrm{bp}$ of the designated control. Second possibility of the multiple peaks is the presence of chimerism in the person involved. Third possibility, which is most important and frequently observed in forensic samples, is the presence of more than one contributors to the DNA sample. Therefore, a rationale method is required to examine the presence of more than two alleles in a particular locus.

The currently available methods for mixed DNA samples remain limited due to the failure of the international standards for DNA testing to recognize the advancements in examination of mixed DNA analysis. We developed a method in which we collaborated selective cell-specific blood typing with DNA profiling and we were able to separate DNA of each contributor from the mixed blood stain belonging to different blood group types, thereby providing with the individual's DNA profile.

We used selective cell-specific blood typing involving the selective $\mathrm{DNA}$ extraction from the leukocytes using $\mathrm{ABO}$ antibodies as it is already known that $\mathrm{ABO}$ antigens are also present on leukocyte membrane [6]. Selective DNA extraction was first reported by Gill et al. [2] and they isolated the DNA from germinal epithelial cells and sperm using differences in the structure of the cell membrane. The method presented here is significant when performing selective DNA profiling to identify a single suspect whose blood type was known beforehand. This method requires attention because, in case the genotypes are $\mathrm{AO}$ and $\mathrm{BO}$, the presence of $\mathrm{H}$-antigen in $\mathrm{A}$ and $\mathrm{B}$ blood types will show small amount of $A$ and $B$ blood cells in the pellet of tube $\mathrm{O}$ and show multiple peaks in the processed 'O' profile. In this situation, supernatant can be used for reverse typing. 
Citation: Kaur S, Budhiraja B, Chaudhary G, Vaishnavi N, Gupta R (2016) White Cell Serology: An Asset for Selective Blood-DNA Extraction from Mixed Stains for STR Analysis. J Forensic Res 7: 319. doi:10.4172/2157-7145.1000319

Page 3 of 3

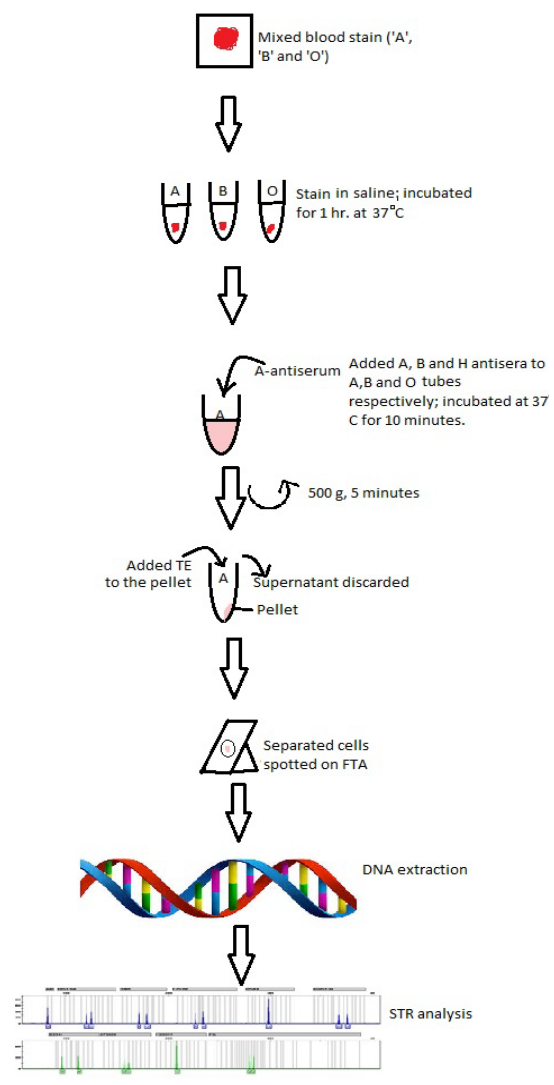

In conclusion, this method is useful in separation of individual DNA from mixed blood stains belonging to different blood types with the application of selective DNA typing from mixed blood stain using specific antibodies of target cells.

The method presented here was performed on fresh blood stain (with 0.1-1 $\mu \mathrm{g}$ of DNA used), examination of old blood stains can also be done to know up to what age of the satin we can extract the useful information from the sample.

\section{Acknowledgement}

The authors are thankful to the Deputy Director Mr. A. K. Srivastava \& the Director, Forensic Science Laboratory, Delhi, India for their valuable support.

\section{References}

1. Chaudhary G, Dogra TD (2015) Raina A-Evaluation of blood, buccal swabs, and hair follicles for DNA profiling technique using STR markers. Croatian Med J 56: $239-245$

2. Gill P, Jeffreys AJ, Werrett DJ (1985) Forensic application of DNA 'fingerprints' Nature 318: 577-579.

3. Mohite PM, Keche A, Anjankar AJ, Ninave S (2011) Effect of Ageing \& Environmental Condition for Detection of Blood Group from Blood Stain Journal of Indian Academy of Forensic Medicine 33: 308-310.

4. Tsukamoto A, Baum CM, Aihara Y, Weissman I (1998) United States Patent Number 5: 750-397.

5. Honda K, Yano S, Nishi T, Iwabuchi Y, Kurosu A, et al. (2013) Selective bloodDNA extraction from mixed stain using $A B O$ antibody for short tandem repeat typing, Forensic Science International: Genetics Supplement 4: e326-e327.

6. Archer GT, Kooptzoff O (1958) Blood group antigens in white cells, Australian J Biol Med Sci 36: 373-382.

Figure 1: Diagrammatic representation of methodology.

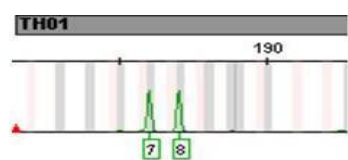

1

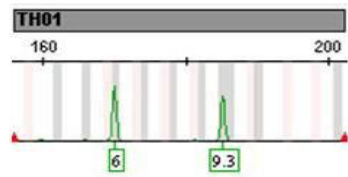

3

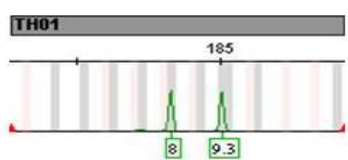

2

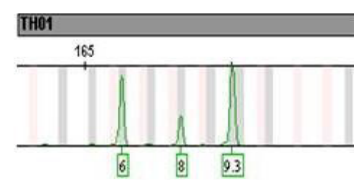

4

Figure 2: Human STR electropherogram on $\mathrm{TH} 01$ loci of individual having blood group 'AA' (1), 'BO' (2), 'OO' (3) and processed 'O*' (4). 